\title{
Review \\ Offsetting Risk in a Neoliberal Environment: The Link between Asset-Based Welfare and NIMBYism
}

\author{
Matthew C. Record
}

Citation: Record, Matthew C. 2021.

Offsetting Risk in a Neoliberal

Environment: The Link between

Asset-Based Welfare and NIMBYism.

Journal of Risk and Financial

Management 14: 547. https://

doi.org/10.3390/jrfm14110547

Academic Editors: Shigeyuki Hamori and Mark Harris

Received: 1 July 2021

Accepted: 16 September 2021

Published: 12 November 2021

Publisher's Note: MDPI stays neutral with regard to jurisdictional claims in published maps and institutional affiliations.

Copyright: (C) 2021 by the author. Licensee MDPI, Basel, Switzerland. This article is an open access article distributed under the terms and conditions of the Creative Commons Attribution (CC BY) license (https:// creativecommons.org/licenses/by/ $4.0 /)$.
Department of Political Science, Drake University, 2805 University Ave, Des Moines, IA 50311, USA; matthew.record@drake.edu; Tel.: +1-515-271-2243

\begin{abstract}
Affordable housing policy in the developed world has been undergoing a systematic commodification for several decades, including a push for homeownership as the normalized tenure and a commodity unto itself. Scholars suggest this push for homeownership is part and parcel of a neoliberal asset-based welfare to supplement, or even outright replace, traditionally defined benefit pension schemes. These policies individualize risk and re-fashion individual citizens as long-term financial planners, navigating the uncertainty inherent in international financial markets and general financial management. Less deeply explored, however, are the perverse incentives this system creates for homeowners to protect their home "investment" by leveraging planning policies, zoning, and land-use restrictions to preserve the community status quo and lock in the value of their home. In a policy environment in which long-term financial risk is individualized and public social welfare and pension systems are relegated to the smallest number of individuals possible, this type of NIMBYism (Not in My Backyard) is rather rational behavior, even as it simultaneously staunches the supply of new housing and drives up prices for non-homeowners. As such, this analysis synthesizes the existing research to make a formal theoretical connection between the neoliberal push for commodified housing, asset-based welfare, and the intractable political problem of NIMBYism.
\end{abstract}

Keywords: housing; pensions; risk management; commodification; neoliberalism; affordable housing; asset-based welfare; homeownership

\section{Introduction}

One of the most daunting policy problems facing much of the developed world is the increasing unaffordability of housing and the political motivations that make providing sufficient housing stock so difficult. For several decades, affordable housing policy in the developed world has been undergoing a systematic process of commodification across multiple dimensions of the policy sub-system (Dewilde and De Decker 2016; Di Feliciantonio and Aalbers 2018; Ronald 2008). Programs specifically designed to apportion housing on a basis other than the pricing mechanism (i.e., need, irrespective of ability to pay) have been consistently relegated to the smallest populations possible, privatized, or replaced with programs directly tethered to market considerations (Dewilde and De Decker 2016; Ronald 2008; Schwartz and Seabrooke 2008; Walks and Clifford 2015). Most developed countries have shifted their focus away from affordable housing to policies that focus on homeownership, irrespective of cost, and particularly in the west (Dewilde and De Decker 2016; Di Feliciantonio and Aalbers 2018; Jones and Watkins 2009; Saegert et al. 2009).

These shifts in policy come amid the hegemonic influence of neoliberal ideology in the western world. In this context, neoliberalism is defined by a preference for the commodified distribution of goods and services, while imagining a robust role for government to specifically support and stabilize markets and stores of capital (Aalbers 2015; Di Feliciantonio and Aalbers 2018; Plehwe 2016; Saegert et al. 2009). Neoliberalism as an ideology-or "thought collective," as Mirowski and Plehwe refer to it (2015, p. 426)-benefits from a 
status of being regarded as neutral, natural, and value-free. Various scholars refer to its intellectual status as "doxa" (Bourdieu 1998), "biological law" (Monbiot 2016), "pensee unique" (Munck 2003; Touraine 2001), or just "simple common sense" (Mirowski and Plehwe 2015, p. 427). Perhaps nothing better encapsulates neoliberalism's canonical status than Margaret Thatcher's putatively oft-repeated acronym TINA—-"there is no alternative" (Hackworth 2007). It is difficult to overstate the success of the moral and political project of neoliberalism as a structured, long-term political and normative theory of economics in the last 40-50 years (Crouch 2011; England and Ward 2016; Hackworth 2007; MacLeavy 2016; Mirowski and Plehwe 2015). Discussing neoliberal policies means contending with both its ideological principles and its "everywhereness" (Prince 2016).

That everywhereness has extended into affordable housing policy subsystems across a number of nations. The neoliberal project is characterized by a generalized preference for homeownership to the near exclusion of government subsidies or programmatic offerings that allocate housing on the basis of need (e.g., Aalbers 2015; De Decker and Dewilde 2010; Dewilde and De Decker 2016; Kadi and Ronald 2016; Ronald and Dewilde 2017). However, the push for homeownership serves as a justification for the commodification of other policy systems as well, most notably social insurance and welfare provision. Under this paradigm, the imputed rent associated with owning one's home along with the store of wealth homeownership provides can serve as a source of welfare into old age, reducing the need for public pensions and other forms of direct old-age benefits from the state (e.g., André and Dewilde 2016; Castles 1998; Chia and Tsui 2019; Delfani et al. 2014; Doling and Elsinga 2012; Kemeny 2005). This policy project is often referred to as homeownership-based, or more commonly, asset-based welfare.

However, the perverse incentives asset-based welfare creates for individual homeowners to offset risk in an environment of residualizing public welfare support are less deeply explored in this literature. For many, if not most, people in the developed world, home equity is the single largest source of wealth they will ever accumulate or be able to access (Causa et al. 2019; Montgomerie and Büdenbender 2015; Ronald and Dewilde 2017). Individual homeowners have a strong material incentive to leverage the institutional mechanisms at their disposal to protect their home from potentially harmful externalities or any form of community change that could impact their investment, even if the actual downside risks are low. The most common mechanisms for protecting one's housing investment from external community transformation are zoning ordinances, community planning, local community engagement, and/or land-use restrictions (Clingermayer 2004; Fischel 2004; Hilber 2010; Ihlanfeldt 2007; McCabe 2016). Scholars have referred to using these mechanisms to prevent community change as the "politics of exclusion" or NIMBYism (not in my backyard) (Fischel 2004; McCabe 2016).

There is a wide-ranging number of expressed and observed motivations of homeowners who engage in NIMBY community activism, including racial resentment, environmental protection, status quo preference, and, indeed, economic self-interest (e.g., Esaiasson 2014; Fischel 2001, 2004). However, rarely does the literature speak directly to how the motivations for NIMBYism would necessarily increase under the auspices of the increased individual financial risks associated with an asset-based welfare program. As uncertainty and risk increase, or even the perception of uncertainty and risk increases, homeowners have increasing motivation to utilize the mechanisms at their disposal to ensure the value of their properties (Fischel 2001, 2004; Ronald 2008; Schively 2007). These behaviors, when applied systematically, can have extremely deleterious second- and third-order effects, such as staunching the supply of available housing, pushing prices upwards, increasing inequality, and exacerbating the risks and uncertainties associated with aging in a society with increasingly limited public pension programs (Delfani et al. 2014; Jones and Watkins 2009; Schively 2007; Schwartz 2010).

This paper synthesizes the existing literature across the social sciences to make much more explicit the theoretical link between asset-based welfare and the incentive it creates for exclusionary (NIMBY) behavior. In Section 2, I synthesize a housing and pension 
system typology to help identify trends in programmatic offerings across the developed world. In Section 3, I argue that the neoliberal project has promulgated policies that push homeownership to the near exclusion of need-based or non-market housing assistance. In Section 4, I review the literature that argues that one of the motivations for centering homeownership is that it makes asset-based welfare and its intendant risks more politically and economically palatable, as a replacement for traditionally defined benefit systems. In Section 5, I outline how these risks incentivize protectionist and exclusionary (NIMBY) behaviors among individual homeowners. Section 6 includes the policy implications and shortcomings of this article's primary argument. Throughout, this paper brings together descriptive empirical data to demonstrate that, while there are substantial variations in housing and public pension/old-age welfare systems, a trend toward the overall commodification of housing systems and public pension programs appears to be occurring across developed nations with many different ideological and policy orientations. I synthesize the existing evidence on the economic and political dynamics of land-use restrictions and NIMBYism through the specific lens of an increasingly asset-based welfare paradigm. The paper closes with a brief discussion of potential policy remedies that could offset or ameliorate the risks associated with a program of asset-based welfare.

\section{A Typology for Understanding Trends in Housing and Public Pension Policies across Nations}

An underlying assumption of this paper's thesis is that the neoliberal preference for commodifying housing and pension systems has, generally, grown in influence over the last several decades throughout much of the developed world. However, that influence will necessarily be attenuated or amplified on the basis of the existing political and economic systems present in different locations, which could potentially manifest in different policies or outcomes. Regions, nations, and subnational entities are obviously complex entities that are subject to an almost infinite number of inter-connected behavioral, cultural, economic, and political institutions, which make them unique and difficult to serve as counterfactuals, even for relative peers.

Nonetheless, observing how changes in institutional construction vary from a comparative perspective serves to crystallize the changes, reforms, and outcomes that cut across all countries, those that cut across (relatively) similar countries, and those that don't demonstrate a clear pattern at all. As such, a typology for similar countries is extremely valuable for the present discussion. Luckily, two such typologies exist and present with a non-trivial amount of overlap, which helps to buttress each one's claim of theoretical validity (See Table 1 on the following page). First, Doling and Elsinga (2012) create a five-category typology (four of which are relevant for the present discussion) that, groups countries semiculturally and regionally, predicated on an observation that countries that share a similar regional or cultural background will tend to have somewhat similar approaches to housing policy and welfare provision/public pensions. Under the Doling and Elsinga paradigm, nations can be roughly characterized along a continuum on a few dimensions; for instance, individual concerns about pension adequacy are lowest in social democratic states and generally higher in both their liberal and Mediterranean counterparts. Furthermore, according to this typology, homeownership is generally lower in both corporatist and social democratic systems, but corporatist systems do not have a particularly active mortgage sector, while social democratic nations do. Welfare spending is, generally, much higher in social democratic and corporatist systems than in liberal or Mediterranean systems. 
Table 1. National housing and pension system typologies.

\begin{tabular}{ccc}
\hline & Doling and Elsinga (2012) & Delfani et al. (2014) \\
\hline Austria & Corporatist & Decommodified Housing/Decommodified Pension System (D/D) \\
France & Corporatist & Decommodified Housing/Decommodified Pension System (D/D) \\
Germany & Corporatist & Decommodified Housing/Decommodified Pension System (D/D) \\
Luxembourg & - & Commodified Housing/Decommodified Pension System (D/D) \\
Belgium & Corporatist & Decommodified Housing/Decommodified Pension System (P/D) \\
Netherlands & Corporatist & Precommodified Housing/Decommodified Pension System (C/D) \\
Denmark & Social democratic & Commodified Housing/Decommodified Pension System (C/D) \\
Finland & Social democratic & Commodified Housing/Decommodified Pension System (C/D) \\
Sweden & Social democratic & Commodified Housing/Decommodified Pension System (C/D) \\
Canada & - & Commodified Housing/Decommodified Pension System (C/D) \\
Norway & - & Commodified Housing/Decommodified Pension System (C/D) \\
Italy & Precommodified Housing/Decommodified Pension System (P/D) \\
Portugal & Mediterranean & Precommodified Housing/Decommodified Pension System (P/D) \\
Spain & Mediterranean & Precommodified Housing/Decommodified Pension System (P/D) \\
US & Mediterranean & Commodified Housing/Commodified Pension System (C/C) \\
UK & Liberal & Commodified Housing/Commodified Pension System (C/C) \\
Australia & Liberal & Commodified Housing/Commodified Pension System (C/C) \\
Ireland & - & Commodified Housing/Commodified Pension System (C/C) \\
Japan & - & Commodified Housing/Commodified Pension System (C/C) \\
New Zealand & - & Commodified Housing/Commodified Pension System (C/C) \\
\hline
\end{tabular}

Delfani et al. (2014) come to similar conclusions about how to categorize national typologies but do so strictly on the basis of processes within a given country, not cultural or geographic characteristics. Delfani et al. (2014) develop their typology across two dimensions: the amount of commodification in the housing sector and the amount of commodification in pension provision. Housing commodification is characterized in terms of "risk pooling", where individuals are primarily reliant upon market institutions for their housing needs (commodified) and reliant upon extended family to mediate housing needs (precommodified) or where there are state mandates, regulations, or direct provision on the basis of need to backstop market provision (decommodified). For the pension indicators, the authors conceptualize the extent to which participation in the primary pension system is mandatory and widely available in a manner that allows for risk sharing and redistribution (decommodified) or primarily voluntary and atomized (commodified). By combining these indicators, the authors conceptualize four typologies: those with both decommodified housing and pension systems (D/D), which roughly comports with Doling and Elsinga's Corporatist type; those with commodified housing but decommodified pension systems (C/D), corresponding roughly to the social democratic type; those with precommodified housing but decommodified pension systems (P/D), corresponding to the Mediterranean type; and finally those nations with both highly commodified housing and pension systems $(\mathrm{C} / \mathrm{C})$, corresponding to the liberal type.

Aside from the fact that each of the two frameworks include several countries the other does not, the two frameworks are quite commensurable across types, with two notable exceptions. Belgium and the Netherlands are both regarded as corporatist in the Doling and Elsinga framework, but Delfani et al. regard Belgium as a precommodified housing system similar to Mediterranean countries and the Netherlands as a commodified housing system similar to the social democrats in Northern Europe. Given that the Delfani framework is slightly more transparent and parsimonious, and since it was also expressly crafted to serve as an independent, rather than dependent variable, I tend to rely more heavily on this framework. Nonetheless, I regard the high level of typological agreement between the two as a strong validation for both.

This national typology will help to guide the descriptive exploration throughout this paper. As the theoretical arguments to follow are laid out, these types will demonstrate when trends confine themselves to specific housing and public pension structures and when these same trends cross typological lines. 


\section{The Neoliberal Preference for Homeownership}

As a widespread set of ideals and political beliefs, what specifically constitutes neoliberalism is often ill-defined, even among scholars, and is poorly understood by the general public, with almost all commonly understood adherents abjuring their association with the word (Crouch 2011; England and Ward 2016; Mirowski 2018; Plehwe 2016). Indeed, given that neoliberalism "draws some of its prodigious strength from that obscurity" (Mirowski and Plehwe 2015, p. 426), it may not be overly conspiratorial to suggest that this ill definition may be intentional or, at least, a happy accident (Monbiot 2016). Nonetheless, it is widely agreed that neoliberalism constitutes a set of ideological principles that state that the market is the primary, best, or even the only means to organize society and that this ideology has been ascendant in much of the western world over the last 40-50 years (Cerny 2008; Goetz 2013; Mirowski and Plehwe 2015; Saegert et al. 2009; Springer et al. 2016). Moreover, neoliberal principles are distinguished from classical, laissez faire liberalism by virtue of a statist position that government intervention into society is acceptable-and even desirable-when those interventions prop up markets or stimulate capital accumulation (Cerny 2008; Hodkinson 2011; Mirowski and Plehwe 2015).

The institutionalization of homeownership to the exclusion of other forms of housingrelated interventions crystallizes the neoliberal perspective. In the first place, homeownership centers market structures around the provision of social services and uses capital markets as a way of organizing who gets what, rather than other normative allocation on the basis of, for instance, need or sustainability (Elledge 2016; Haffner 2009; Kadi and Musterd 2015; Malpass 2008). Ronald and Dewilde (2017) summarize this tension thusly: "the shift in policy from housing as a service to housing as a commodity typically marked a golden era in the expansion of housing markets and owner-occupancy rates" (p. 4).

Conversely, the ideological preference for a society organized around homeownership demonstrates the neoliberal project's comfort with government intervention into the market, so long as it supports new capital accumulation and creates market opportunities for private enterprise. Most obviously, as any liberal ideological movement would prefer, the push toward increasing homeownership in western societies has been marked by a roll-back of government banking and mortgage finance regulation (Aalbers 2009; Mirowski 2013; Schwartz 2010). However, state participation in the homeownership market extends much further. Many governments have taken direct action to ensure the wide availability of mortgage credit (Aalbers 2015; Dewilde and De Decker 2016; Haffner 2009). In the U.S., for instance, the government spun off quasi-public agencies with the purpose of securitizing originated mortgages to ensure a steady flow of credit availability to new borrowers (Aalbers 2011; Mirowski 2013; Sowell 2011). These organizations, Fannie Mae and Freddie Mac, while nominally for-profit organizations, acted with a widely assumed-albeit tacit-government backstop that became quite explicit when both organizations entered government conservatorship after the mortgage crisis of 2008 (Aalbers 2011; Schwartz 2010). In the UK, the government sold off council housing stock in order to stimulate government revenue and transform residents to homeowners (Ronald 2008). Governments from the U.S. to Ireland to Belgium to the Netherlands further offered tax incentives and subsidies to encourage homeownership by defraying mortgage costs, providing secondary financial support to homeowners, and incentivizing developers to create new single-family homes for the explicit purpose of owner occupation (De Decker and Dewilde 2010; Gurran and Bramley 2017; Schwartz 2010).

These interventions have created nations of homeowners throughout much of the developed world (see Figure 1). 


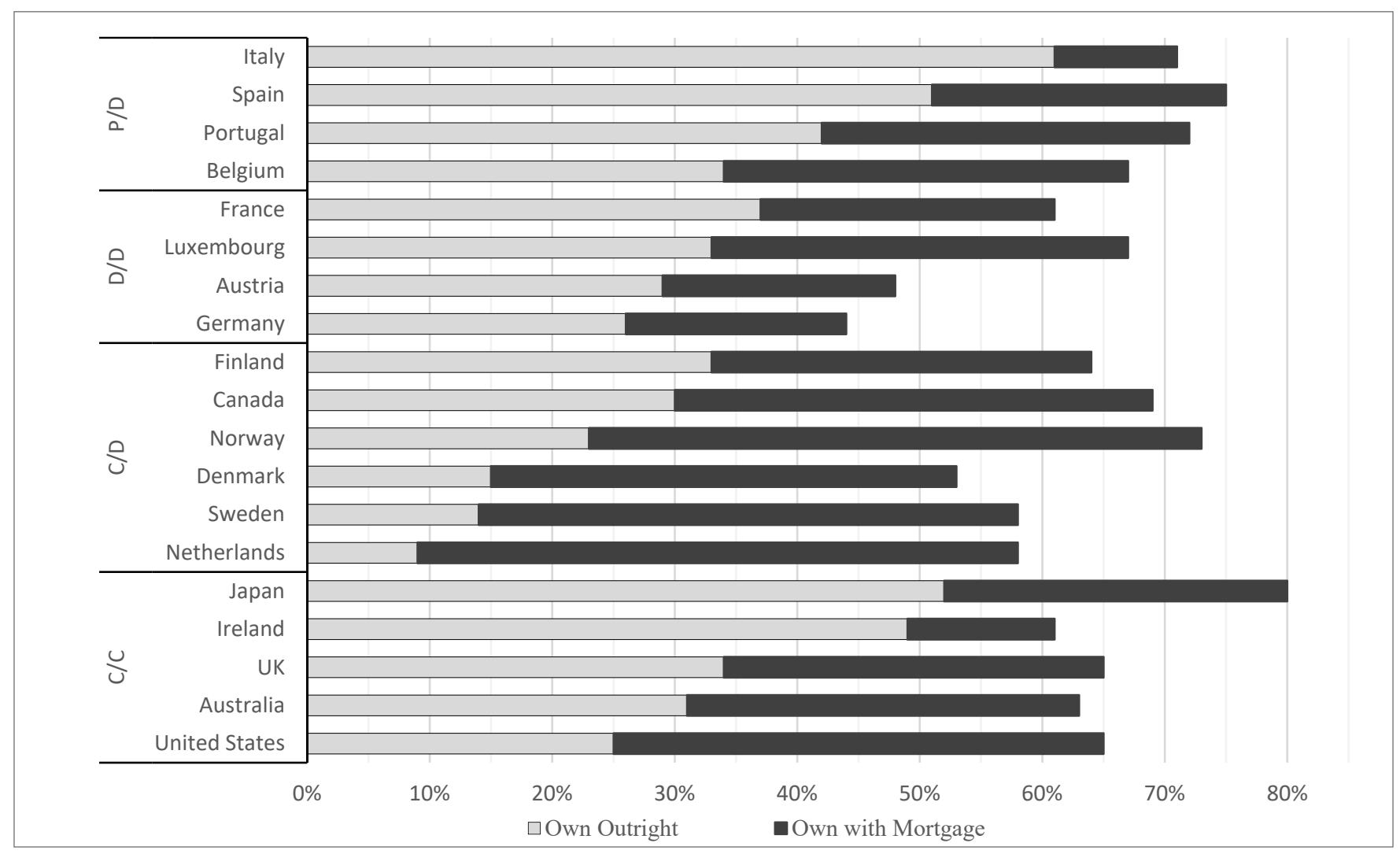

Figure 1. Homeownership rate by nation. Owners with a mortgage vs. outright owners, 2019. Source: (OECD 2019; OECD Affordable Housing Database 2021b). Note: Mortgage breakdown of those with and without a mortgage not available for New Zealand.

Homeownership has been quite common in the precommodified Mediterranean, (even more common, in fact, than in the more liberalized Anglophone nations), with a tradition of real estate transfers among families that remains a central facet of those societies (Delfani et al. 2014). However, the prevalence of homeowners with a mortgage (home debtors) in, for instance, precommodified Belgium or decommodified France and Luxembourg, suggests that there may be some transformation occurring, since non-market real property transfers are less likely to involve formal lending ${ }^{1}$. Indeed, this is further supported by trends in overall homeownership rates. Countries that have historically provided social housing, like France, the Netherlands, Sweden, and Germany, are among the developed nations that have seen the largest increases in homeownership in the last 40 years (Christophers 2013; Ronald and Dewilde 2017; Wind et al. 2017). This suggests that the push for homeownership may be cutting across societies and welfare state configurations (see Figure 2).

It is important to note that, politically, this drive for homeownership was not invented entirely through government support, against the will of the people, in these countries. The literature has long established a sincere desire among a portion of the population across many of the countries discussed here to transition from renting to homeownership (Amior and Halket 2014; Jones and Watkins 2009; Stephens et al. 2015). However, the construction of homeownership in a society can be complex within the context of a neoliberal paradigm, as government policy could accurately be described as an effect of a societal desire for homeownership, but could also rightly be described as a cause. Beer and Faulkner (2011) outline several of the facets that drive young people, in particular, away from rental housing, including high rent, poor quality, and relatively higher housing insecurity. However, these are not immutable characteristics of the rental market, as much as an outgrowth of government priorities. As increasing neoliberal influence led to an institutionalized housing model centered almost entirely on homeownership, it simultaneously de-emphasized 
intervention in the rental market, making that tenure less attractive and less accessible, even in countries where social housing was, previously, more readily available and relatively destigmatized (Aalbers 2015; Malpass 2008). As such, it can become difficult to disaggregate exactly how much the extension of homeownership in commodified and decommodified housing systems alike has been driven by a sincere desire for tenure and how much is an instrumental response to government policy (Haffner 2009).

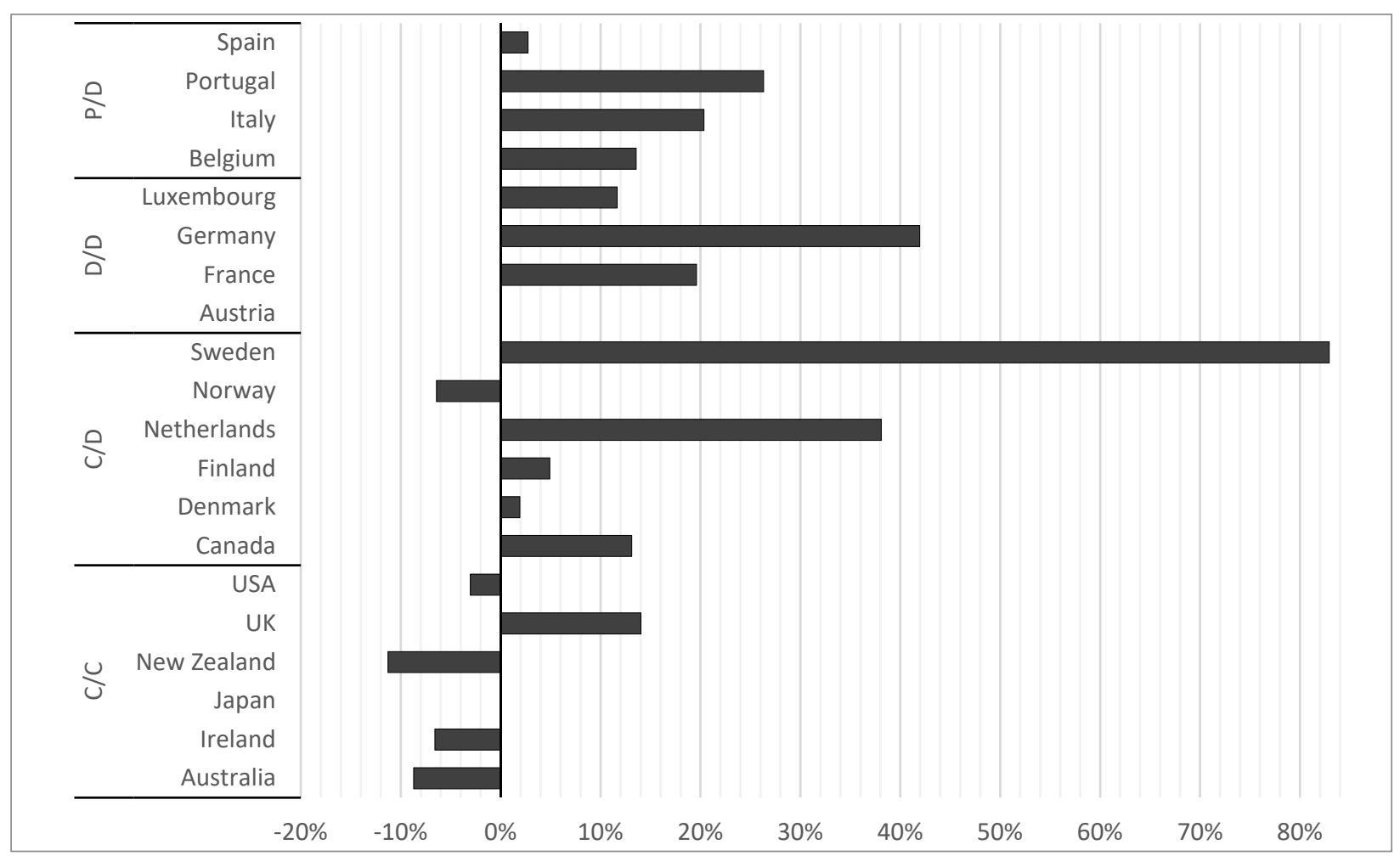

Figure 2. Percent change in homeownership rate, 1980-2019. ${ }^{2}$ Note: Luxembourg homeownership rate not available from 1980; change tracked since 1997.

\section{Homeownership as Asset-Based Welfare}

The neoliberal project prefers the commodification of housing, at least in part, because it serves as a useful bridge to asset-based welfare. Under this paradigm, the state's role in the housing system is primarily to help expand credit opportunities that facilitate homeownership and create tax incentives that make opting into homeownership more attractive (Di Feliciantonio and Aalbers 2018). With as much of the population opting into homeownership as possible, the state can commensurately reduce direct welfare provision and pension costs (André and Dewilde 2016; Chia and Tsui 2019; Delfani et al. 2014; Doling and Elsinga 2012; Hollanders 2016). Homeownership is a particularly effective implementation of this logic, because homes not only act as a store of wealth, with reasonable rates of return on investment, but also lock in housing costs as individuals enter their elderly, nonworking years (Kemeny 1980; Ronald 2008). Elsinga and Hoekstra (2015) refer to this as the "Janus Face" of welfare, predicated on increasing homeownership. However, they assert that by trying to utilize homeownership as a mechanism for alleviating poverty and ameliorating state responsibility for welfare ordinarily provided through pensions, a number of other substantial policy problems are created, most notably by greatly increasing both the wealth gap between homeowners and non-homeowners and creating barriers to entry for non-homeowners.

Increasingly among developed nations, and particularly in more liberalized Anglophone countries, traditional defined-benefit pensions at both the state and employer level 
are being rolled back or de-emphasized in favor of programs that call on individuals to take greater charge of their future financial well-being (Brainard and Brown 2018; Izuhara 2016; Jeszeck et al. 2017; Santos 2016). As summarized in Ronald (2008):

This underpins the broader commodification of social relations, with market practices constituted as the best and most appropriate means of welfare provision, and state mediation the least. This inevitably supports the reduction of public spending and the transfer of economic and social risks from the state to individuals, which underlie a more globalized model of a competitive and market-orientated neo-liberal state.

De-emphasizing defined-benefit pensions, particularly those that emanate from the state, naturally raises questions about welfare adequacy and the wisdom of shifting risk from collectivized pools to individual actors. Where citizens are required to navigate the complexities of financial planning and managing risk, the resultant anxieties about their ability to do so and the extent to which backstops exist to protect them if they fail become far more salient (Bond and Doonan 2020; Hershey et al. 2007; Litwin and Meir 2013).

An often-implicit assumption in the broader move toward asset-based welfare-and commodification generally - is that reduction in the government's involvement in public welfare provision is ipso facto desirable (Ronald 2008). The state could, in theory, provide a public pension or help backstop a robust private pension system while simultaneously taking policy steps to ensure a widely accessible path to affordable homeownership. In practice, however, asset-based welfare has often been utilized as a mechanism to elide the state's welfare responsibility to those for whom pensions and other income-based policies are intended (Doling and Elsinga 2012; Stephens et al. 2015). According to Doling and Elsinga "[h]ousing is often viewed as a substitute not only for the perceived inadequacy of government pension provision but for government provision in other areas, especially social and health care needs" (2012, p. 22). That asset-based welfare has tended to function in this manner is extremely important to note because, among the academic work generally supportive asset-based welfare systems, authors have taken pains to explicitly state that it would be most effective when utilized as a complement to existing defined-benefit systems, not as a replacement (De Decker and Dewilde 2010; Sherraden 2005).

However, Figure 3 suggests that replacement may be what is occurring, at least in some locations. Total expenditure on cash benefits has gone up or remained steady as a percentage of GDP in nearly every country in this study, with the notable exceptions of Ireland and the Netherlands. However, even as old-age cash expenditures increase, that growth trails the growth in the $65+$ population in many nations.

As the literature predicts, liberal nations with commodified pension provision have all seen cash benefit growth that fails to keep pace with their elderly population. However, with the exception of the Precommodified/Decommodified (P/D) countries, all nation types see at least one instance of pension growth trailing elderly population growth, such as the Netherlands and Canada among the C/D nations and Germany among their D/D counterparts. Non-P/D countries where pension growth has kept pace with or even exceeded elderly population growth, such as in Finland, Austria, and France, are rarer. Aggregating by type, the mismatch between pension growth and 65+ population is by far the greatest in the commodified C/C countries and least in the decommodified D/D countries, with the C/D countries falling in the middle. With the exception of Belgium, the $\mathrm{P} / \mathrm{D}$ countries have all seen pension provision become more generous relative to old age population growth. 


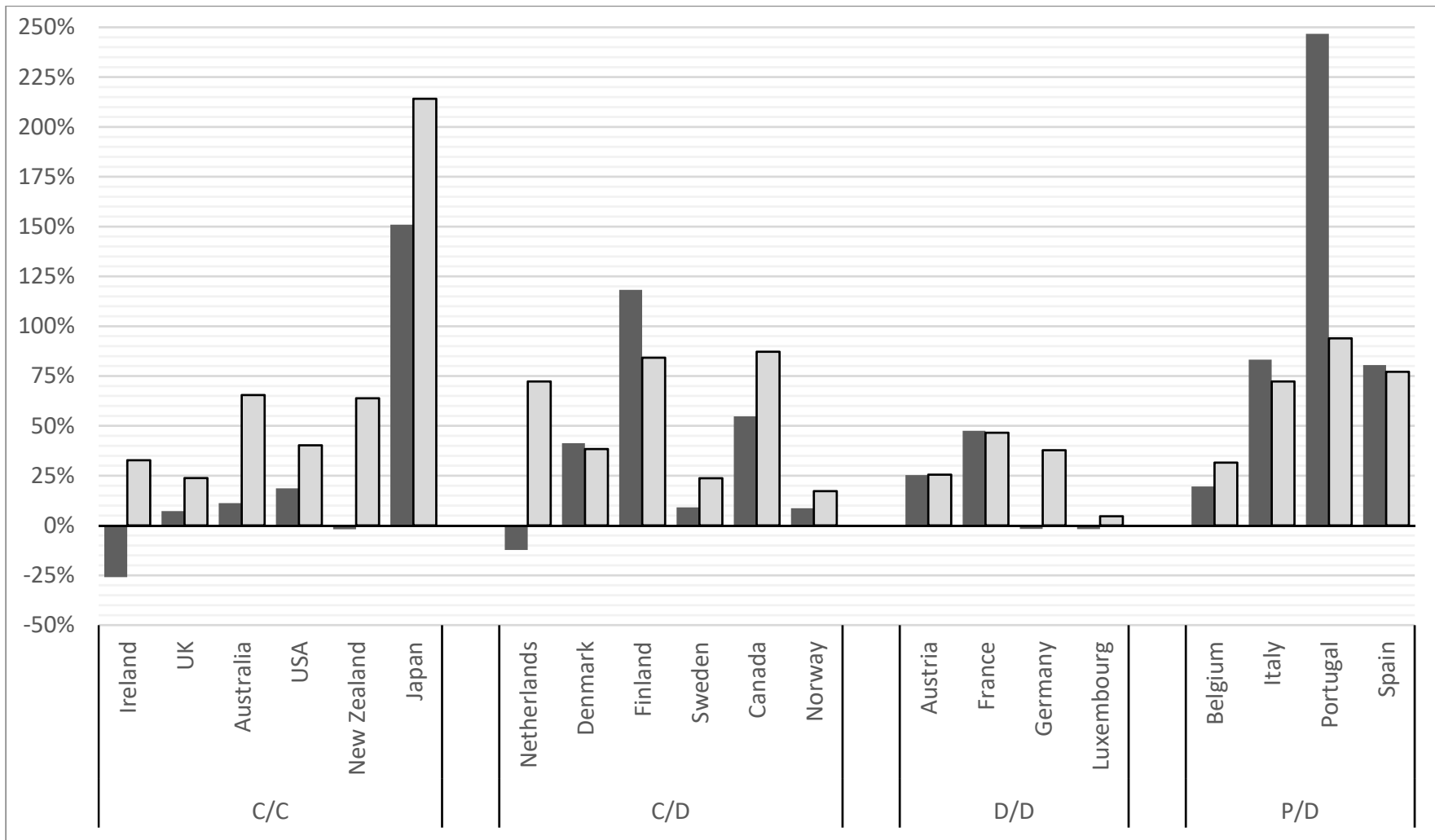

- Change in Old Age \& Survivor Cash Benefits (As a Percentage of GDP) aChange in Population 65+ (as a Percentage of Population)

Figure 3. Change in Public Old-age Cash Benefits and 65+ Population, 1980-2017. Sources: (OECD 2021b; World Bank 2021).

Where it occurs, a successful shift to asset-based welfare requires substantial changes in the behaviors and expectations of individual consumers. An asset-based system, in theory, presupposes a population that has already habituated to the mental and budgetary habits of a financialized agent, including foregoing consumption, implementing savings plans, and building individual long-term safety nets, even though this habituation is largely nonexistent (Izuhara 2016; Montgomerie and Büdenbender 2015; Sherraden 2005; Watson 2009). Academic work stressing the benefits of asset-based welfare implicitly assumes that the governance system will craft systemic networks and policy safeguards to insure against inevitable mistakes, ignorance, panic, and plain bad luck (Izuhara 2016; Kadi and Ronald 2016; Montgomerie and Büdenbender 2015). However, outside of tax incentives that make asset-based mechanisms more attractive on an individual basis, this systemic network has not materialized. Finlayson (2009) asserts, in fact, that the practice of transitioning to an asset-based system has not been preceded by meaningful training or educational support.

This learn by doing approach is an important element of the transition to asset-based welfare because socialized welfare arrangements, by virtue of their design, involve higher levels of risk pooling (Ronald and Dewilde 2017). By placing individual asset-building at the center of the state's welfare provision, and by further placing housing at the center of an asset-based paradigm, financial and government institutions are radically shifting risk from more diversified, collectivized pools to individual homebuyers and their communities (Köppe 2015; Saegert et al. 2009). In effect, an asset-based housing system shifts risk from institutions with specific resource and knowledge bases designed to manage and absorb financial risk to individuals who are meant to act as wealth managers on top of their existing day-to-day professional and personal responsibilities. 
To the extent that policy has eased the transition into an asset-based homeownership paradigm, it has done so by easing access to credit. Indeed, extending homeownership to underserved populations for the purposes of wealth building was a central justification for the expansion of the subprime mortgage market (Forrest and Hirayama 2015). Given the stagnating market wages among lower quartiles, during this transition to an assetbased welfare system, capital accumulation among lower income families was primarily accomplished through an accumulation of debt (Aalbers 2015; Di Feliciantonio and Aalbers 2018; Ronald 2008; Santos 2016).

Figure 4 demonstrates that individual household assets grew at a rate that was greater than the growth of household debts in many, but certainly not all, developed countries. Among the C/D countries, household debt has increased most consistently, likely owing to the greater prevalence of pre-existing homeownership among citizens of those nations. However, with the exception of Canada, household assets have grown much more than debt among this cohort since the mid-1990s. Among the D/D type, debt growth has been more mixed, with France observing both debt and asset growth similar to their C/D counterparts, but Germany and Austria seeing substantial asset growth, with little to no increase in aggregated debt. The P/D nations have almost all seen debt that has grown at the same rate as asset growth or greater, possibly reflecting a greater prevalence of marketized mortgage lending relative to the informal family structures that predominated in prior generations. Luxembourg, similarly, saw much greater growth in debt than assets, unlike most of the peer nations of its type. The liberal $\mathrm{C} / \mathrm{C}$ countries have by far the most mixed outcomes, including the two most extreme examples. The $\mathrm{C} / \mathrm{C}$ cohort contains both the only country that saw assets growing against a reduction in real household debt (Japan) and two countries that saw large debt increases against modest (Australia) or negative (New Zealand) asset growth. At the very least, this indicates that, potential aggregate financial outcomes have a much higher variance in a commodified or commodifying system, relatively speaking, which could hypothetically impact the risk assessment of individual homeowners, either explicitly or subliminally.

The original intent of asset-based welfare was to shift attention away from consumptionbased direct income programs towards assets that, scholars have asserted, better reflected actual disparities in quality of life (Cook 2001; Izuhara 2016). However, there is evidence to suggest that transitioning to asset-based homeownership policies exacerbates inequalities between homeowners and renters. In their study of elderly poverty in Belgium, De Decker and Dewilde (2010) asserted that elderly homeowners are less likely to experience poverty than elderly renters, but they are still more likely to experience poverty than the general population. Moreover, asset-based homeownership requires high levels of uptake. The literature has long established that homeownership is deeply tied to class and economic status, and thus it will likely require greater policy intervention to universalize homeownership beyond the levels that currently exist (Forrest and Hirayama 2015; Ronald and Dewilde 2017; Stephens et al. 2015).

Hollanders (2016) asserts that the models demonstrating that homeownership reduces individual-level poverty fail to account for how these shifts create winners and losers:

$[\mathrm{H}]$ ousing wealth is not wealth on the aggregate level ... Rising house prices are advantageous for individual house owners ... [t]hey are however disadvantageous for (potential) house buyers and for renters insofar as rental prices co-move with house prices. Rising prices redistribute and do not add to total production and economic growth ... [c]hanging house prices lead to unpredictable, unfair and inefficient redistribution of wealth.

$$
\text { (Hollanders 2016, p. 406) }
$$

Asset-based policies aimed at increasing homeownership also increase prices in the absence of other concurrent interventions, such as government investment in public housing or liberalization of land-use restrictions (Davis and Palumbo 2008; Glaeser et al. 2005; McIntyre and McKee 2012; Schwartz 2010; Sowell 2011). Thus, asset-based homeownership policies don't appear to increase aggregate wealth or reduce aggregate poverty, they simply 
make winners out of people who can obtain homeownership and losers out of those who cannot (Kiyotaki et al. 2011). Therefore, perhaps the most salient cleavage that asset-based homeownership creates is between older generations, which are disproportionately comprised of homeowners who benefit from increasing prices, and younger generations, which are disproportionately comprised of non-homeowners who do not. Forrest and Yip (2011) argue that younger generational cohorts are systematically excluded from homeownership in ways that previous generations were not (as cited in (Aalbers 2015); see also (McKee 2012)). In a system that has shifted away from consumption- and income-based welfare to an asset-based model, these younger generations suffer when they are systematically excluded from the primary state-supported asset by high prices. Often, younger cohorts rely on generational transfers of wealth in the form of loans, gifts, or inheritances to finance homeownership. In an increasingly asset-based system, accompanied by commensurately increasing barriers to entry, inequalities between homeowners and non-homeowners can be compounded generation over generation (Di Feliciantonio and Aalbers 2018; Izuhara 2016; Ronald and Dewilde 2017). Thus, while not necessarily an inherent condition of asset-based welfare interventions generally, or asset-based homeownership specifically, both of these things have had a regressive impact on families in the economies in which they have been employed in practice (Hollanders 2016; Izuhara 2016; Sherraden 2005).
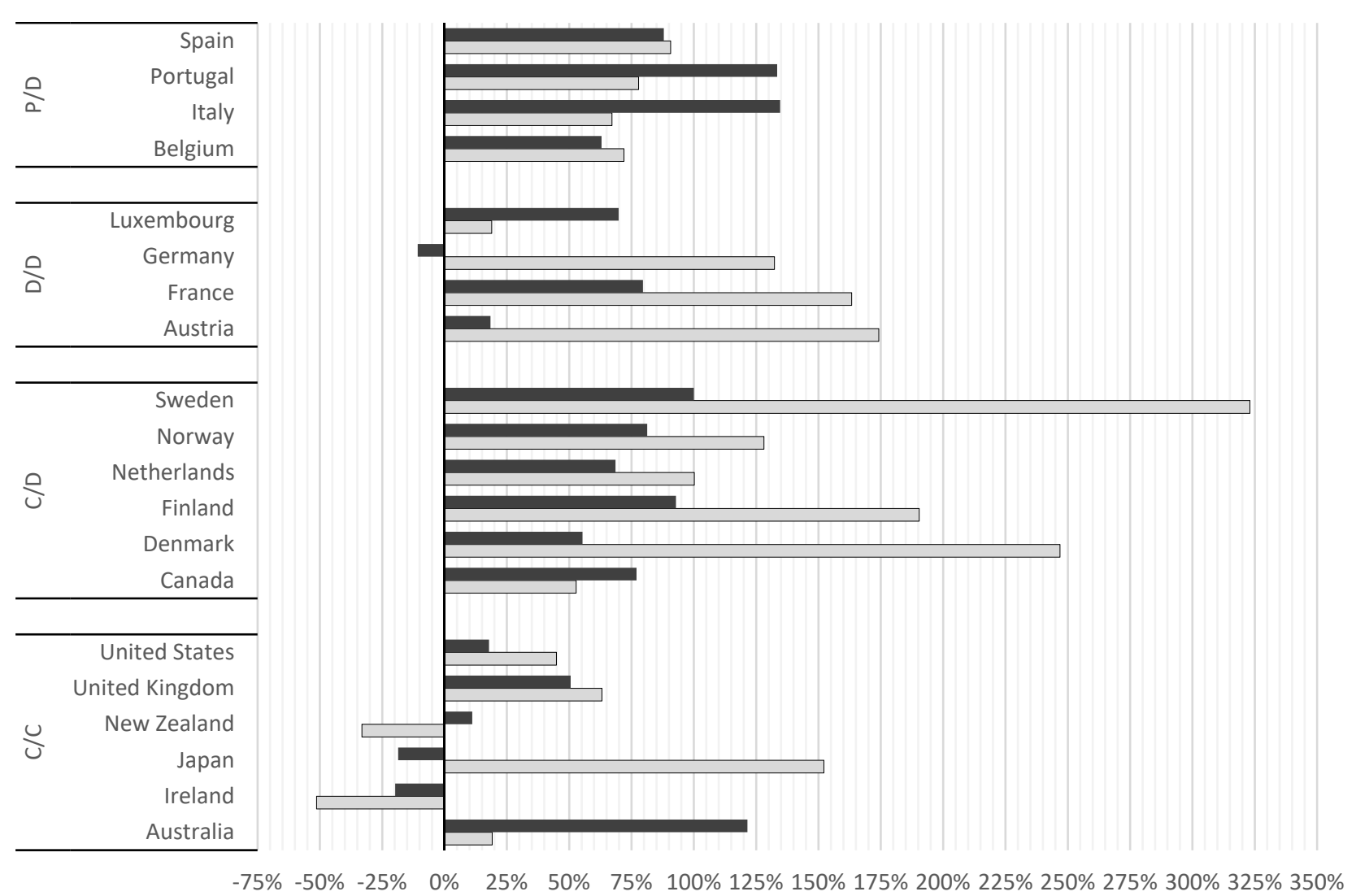

$-75 \% \quad-50 \%-25 \% \quad 0 \% \quad 25 \% \quad 50 \% \quad 75 \% \quad 100 \%$ 125\% 150\% 175\% 200\% 225\% 250\% 275\% 300\% 325\% 350\%

- Change in Household Debt, Loans and Debt securities (Percent of GDP) $\square$ Change in Household Assets (Percent of GDP)

Figure 4. Percent change in household wealth and household debt, 1995*-2019. Source: International Monetary International Monetary Fund (2020); OECD (2021a). Note: Asset data for New Zealand are unavailable before 2007 and unavailable for Ireland before 2001. Household debt data available for Luxembourg begin in 2002. Percent change calculation for each of these nations is baseline to those years. 


\section{Asset-Based Welfare as an Incentive for Exclusionary Land Use}

It has long been accepted in the literature that land-use restrictions staunch the supply of both new housing and higher density housing in communities (Davis and Palumbo 2008; Deng 2003; Glaeser et al. 2005). In a market that functions as theoretically intended, supply would meet demand, stabilizing prices. However, restrictions on land use introduce friction into the system, which creates a persistent disequilibrium tending towards under-supply (Blumenthal et al. 2016). This phenomenon is best observed in the increasing share of land in overall property values (Davis and Palumbo 2008; Glaeser et al. 2005). The analysis of Knoll et al. (2017) of existing pricing records in more than a dozen developed countries confirms extreme land value increases relative to overall house price dynamics in recent decades, suggesting that the suppression of higher-density land use is a major driver of costs.

A similar trend has happened in the United States over the last 40-50 years (see Figure 5). In the U.S., land represents a great percentage of overall real property values, as demonstrated by most of the cities in the West and Midwest. It is worth noting that most cities that saw land decrease as a percentage of homes are single-family dominated cities like Phoenix and Dallas, which have few geographic constraints and are able to sprawl and, develop new outlying areas in ways that places like New York and San Francisco cannot (Badger and Bui 2019). As such, there does not appear to have been many American cities that have substantially increased their housing availability by way of greater density, even as land prices continue to rise ${ }^{3}$.

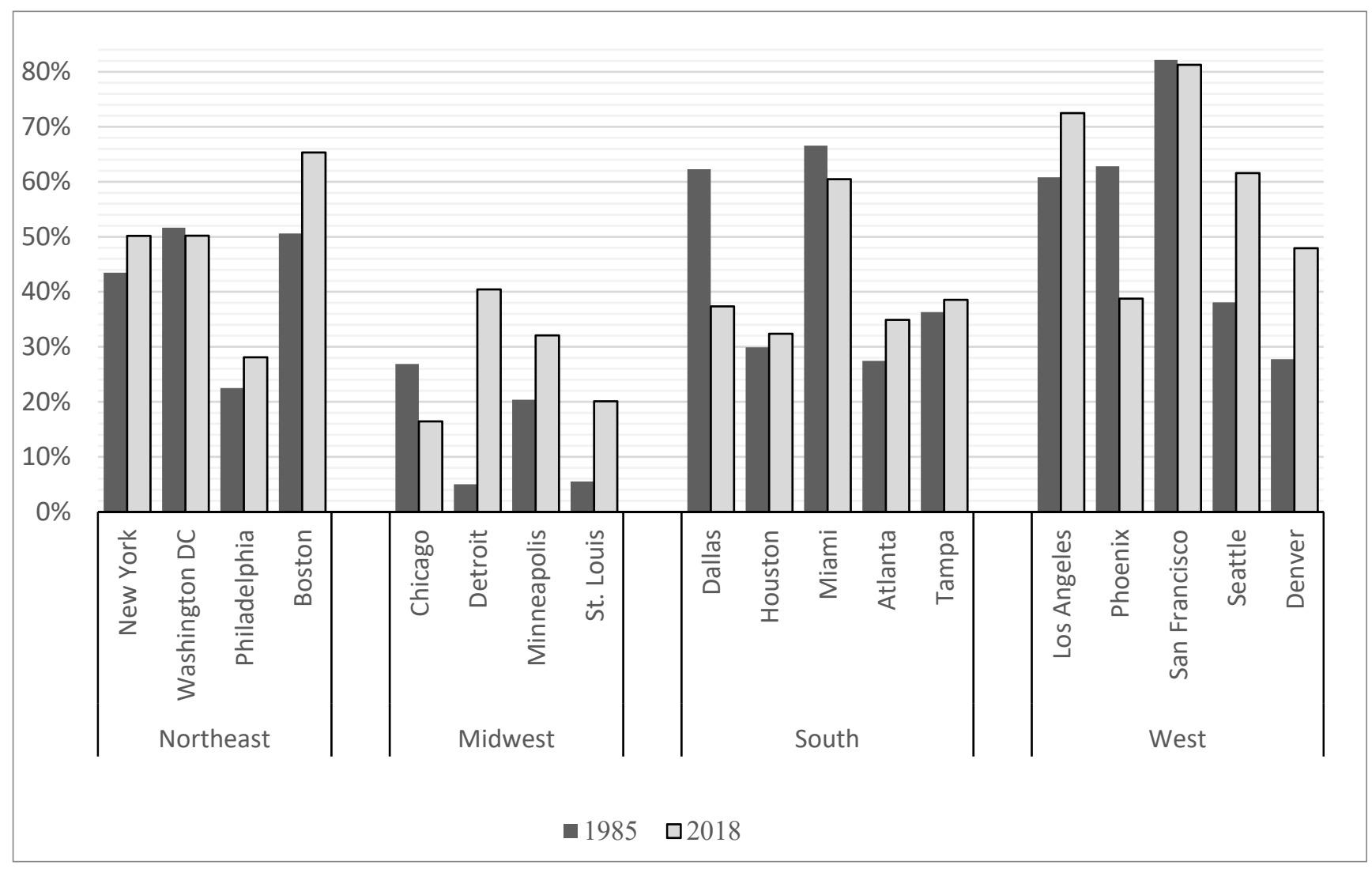

Figure 5. Land value as a percentage of home value, selected U.S. cities-1985, 2018. Sources: (American Enterprise Institute 2021; Davis and Palumbo 2008).

Much of the existing literature on land-use restriction focuses on the U.S., where formal zoning practices date back to roughly the 1910s and 1920s, although municipalities like San Francisco implemented substantial land-use restrictions earlier (Fischel 2004). 
However, the practice of planning land use in communities, whether formally or informally, dates back much farther. Common law arrangements and informal restrictions exerted substantial influence on development and protected homeowners throughout the late 19th and early 20th centuries in the U.S. (Fischel 2004; Hart 1996). Nonetheless, a curious phenomenon emerges from this literature. While modern zoning and land-use restrictions began to take shape in the U.S. in the 1910s and 1920s, and the Supreme Court codified them into federal statute in $1926^{4}$, the impact of land-use restrictions either doesn't materially suppress new housing supply or goes mostly unmentioned prior to the 1970s. Some observers suggest that the 1970s saw a "rapid spread" of new land-use restrictions implemented in the name of preserving green spaces and community historical character and protecting the environment (Sowell 2011). These studies often treat housing restrictions as an exogenous constraint, with the underlying political, social, and cultural motivations generally unexplained or unexplored (e.g., Hsieh and Moretti 2015). By implication, if local governments would simply allow the housing market to operate naturally, housing supply would expand to meet the needs of its communities. Instead, it chooses not to do so thanks to a misguided preference for state control over market provision.

General criticisms of land-use restrictions as a failure of the government tend to overlook the class dynamics that underlie them. Historically, land-use restrictions and the regulation of community development have been implemented as a concession to single-family homeowners (Deng 2003; Fischel 2004). Moreover, evidence suggests that wealthier-and thus generally more politically engaged - communities often have higherfriction regulations, with fewer exceptions granted (Matejczyk 2001). A robust literature has asserted a connection between the employment of land-use restrictions and community opposition to a variety of facilities, social services, industrial concerns, and housing (Deng 2003; Esaiasson 2014; Hankinson 2018; Matejczyk 2001; Santiago et al. 2001; Wolsink 2004).

As established earlier, the neoliberal project of housing commodification has pushed a policy agenda wherein homeownership is the preferred and normalized tenure; however, homeownership itself, shifts attitudes in a number of relevant ways. Research suggests that homeownership is broadly associated with a higher propensity to participate in political processes as well as higher levels of conservative attitudes and a status quo bias (Dietz and Haurin 2003; Gilderbloom and Markham 1995; Kingston and Fries 1994). Moreover, the pattern of association between homeownership and political ideology is not at all clear, as these attitudes have historically cut across partisan lines. Irrespective of differences in political attitudes, it has long been established that homeowners demonstrate higher levels of political participation with their local community than their non-homeowner counterparts (Dietz and Haurin 2003; Gilderbloom and Markham 1995; Kingston and Fries 1994; Rusch 2012). Homeowners represent a relatively large and politically powerful constituency that is consistent in its opposition to new large-scale development or increased density (Glaeser and Ward 2009; Hankinson 2018; Ihlanfeldt 2007; Rothwell and Massey 2009). Thus, housing commodification's preference for near-universal homeownership has created a large class of stakeholders in the housing policy subsystem who are more or less focused on maintaining the housing and community development status quo.

If Sowell's construction of the community usage of land-use restrictions was the result of a generalized preference for government interventionism, we would expect the prevalence of these policies to wax and wane with the popularity of interventionist ideologies, but there is little evidence that this has happened. Evans (2008) points out that through decades of British political change, upheaval, and concomitant transitions in political attitudes during the modern era, regard for and the use of planning restrictions remained surprisingly stable, even as nominally market-first preferences took hold ${ }^{5}$. In the U.S., differing levels of government often appear to be working at cross-purposes, reflecting differences in the locus of power for homeowners as a constituency. Central or federal governments will often provide relatively generous demand-side subsidies to both renters and, especially, homeowners, while state and local policies find increasingly baroque mechanisms and justifications for restricting density (Moroni 2016). The extent 
to which homeowners consistently demonstrate NIMBY political behaviors and avail themselves of land-use restrictions to prevent new housing construction and greater density does not appear to be easily explained by a simple ideological preference for or against government regulation.

For this reason, Breton's (1973) notion that land-use restrictions are used as a form of home-value insurance among homeowners appears to have much to recommend it. The inherent organization of land use is biased towards the status quo. The relevant stakeholders prior to the completion of new infrastructure or housing are the existing residents of a community, and they are likely to see any change in the status quo as the creation of social benefits for an unnamed other at their own expense. The "beneficiaries" of these policy changes are not identifiable ex ante and don't participate in the decision making, since they are not yet community stakeholders (Evans 2008).

In short, homeownership is extremely risky, particularly for those who do not have high levels of preexisting wealth (Brennan et al. 2017; Fischel 2004). Housing wealth is immobile and difficult to liquidate, which creates extremely strong incentives for homeowners to stringently curate the built environment their housing occupies (Ryan-Collins et al. 2017). Much of the existing research suggests that while homeowners will often feel compelled to couch their opposition to new housing in civic-minded terms like preservation, environmentalism, or justice (Sowell 2011), these are often post facto justifications for what is, in all likelihood, the pursuit of their perceived economic self-interest (Elster 1986; Esaiasson 2014). Thus, within the context of a commodified housing system, and particularly under the auspices of a neoliberal paradigm that does not shy away from residualizing both housing market support and socialized pensions (Mirowski and Plehwe 2015), a generalized preference for government intervention in land use is a rational response to the set of incentives created. The commodification of housing encourages entire cohorts of actors in the housing policy subsystem to use nearly any institutional mechanism at their disposal to fight new development or increased density. This is how, ironically, tethering housing provision so closely to the pricing mechanism created a large, robust, and extremely risk-averse population of homeowner NIMBYs who make supra-market land use regulations such a powerful and desirable tool. In such an environment, as long-term financial risk or perceived long-term financial risk increases, so too does the incentive to engage in NIMBY behaviors.

In the literature, the primary focus on NIMBYism has been the way it limits useful housing supply and ultimately drives up prices (Dewilde and De Decker 2016; Hankinson 2018; Thlanfeldt 2007). According to Clingermayer (2004), "land-use controls such as minimum lot sizes, restrictions on multifamily dwellings and mobile homes, and architectural design specifications often have substantial impacts upon the availability of housing at prices that low-income families can afford" (p. 378). The incentive to use these effective political tools only increases as asset-based welfare increases the risk or perceived risk associated with homes as a primary component of long-term financial security, driving up prices for those who were not fortunate enough to have already achieved homeownership. While the data does not allow us to observe long-term trends, we can see a marked difference in housing availability by nation type (see Figure 6). The D/D countries have markedly fewer individuals who are income-constrained renters than their counterparts in other nations and also have the lowest levels of income constraint among homeowners with a mortgage. The C/D countries also have relatively low numbers of income-constrained homeowners but among the highest income proportions of income constraints for renters. The C/C and P/D countries appear to have high levels of income-constrained residents across the board. 


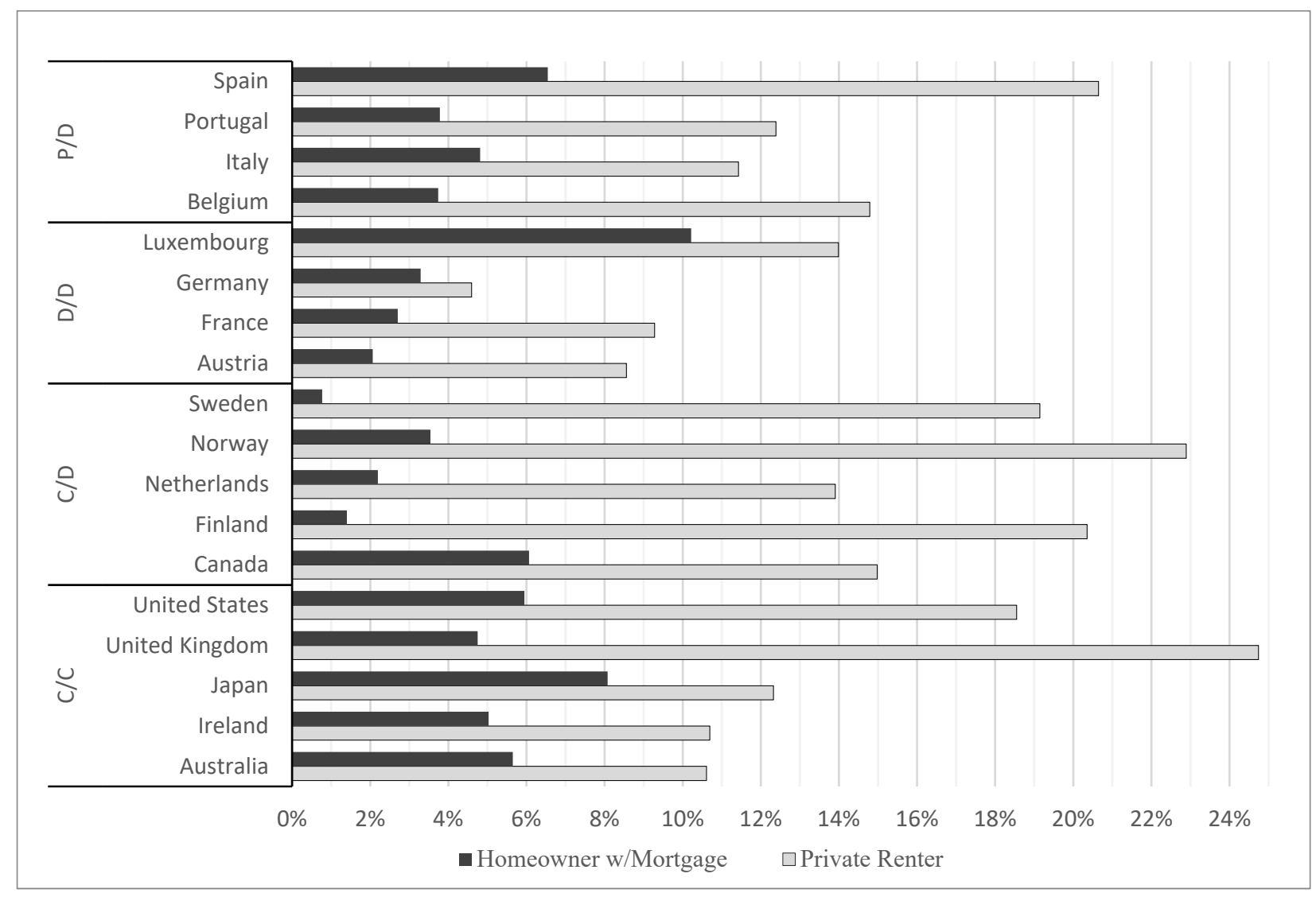

Figure 6. Share of population spending more than $40 \%$ of disposable income on mortgage and rent, by tenure-2019 or most recent year. Source: OECD Affordable Housing Database (2021a, 2021b).

This provides suggestive empirical support for the primary theoretical thesis of this article. De-commodified systems may disincentivize NIMBYism, relatively speaking, as fewer people have home investments to protect in the first place. Moreover, de-commodified pension systems in those countries that have them may result in citizens being less anxious about changes in the economic or physical space around their home due to the reduced financial risk they face in old age, disincentivizing pursuit of NIMBY behaviors.

\section{Conclusions}

In the context of present behavioral and structural factors, homeownership is an effective way for middle-class households to build wealth in most developed countries. However, due to the exclusionary nature of how homeownership policy was originally pursued-particularly in commodified contexts-and given the fact that mechanisms of exclusion have migrated from lending and welfare decisions at the highest levels of government to local zoning policies and community planning, there are authors who argue that homeownership is ipso facto regressive (Hankinson 2018; Izuhara 2016; Sherraden 2005). As such, these scholars tend to recommend a policy suite that de-emphasizes or altogether ceases government intervention to encourage homeownership while introducing more need-based programs regardless of housing type or tenure (McCabe 2016; Sager 2011).

Other, slightly more incremental reforms tend to focus on de-commodifying housing subsystems or reducing the financial incentive to view one's own housing first and foremost as a stock of asset wealth by reducing the financial risks associated with aging and disability through policy reforms in both the pension and housing sub-systems. On the pension side, the literature broadly asserts that public pensions themselves could serve as exactly this form of social insurance. Scholars suggest a pivot back toward defined- 
benefit social welfare schemes that diversify risk across an entire population (Doling and Elsinga 2012; Ronald and Dewilde 2017; Stephens et al. 2015). More specifically, Bond and Doonan (2020) identify long-term care costs as perhaps the single most salient long-term financial risk facing most individuals and propose more robust government interventions in commodified systems to ensure sufficient care, perhaps without necessitating a full-scale retrenchment of new investment in defined-benefit programs.

On the housing side, scholarship suggests that, the community orientation of land use is, at least to an extent, in and of itself, the main cause of exclusionary political behavior. A more aggressive implementation of legal remedies to force communities to build more affordable housing and/or a greater focus on affordability needs from a regional or national perspective could reduce the political salience of existing homeowners' preferences (Ihlanfeldt 2004). However, such strong-arm tactics could just as easily inflame the problem. A number of scholars suggest rolling back lender- and borrower-side subsidies that have the effect of encouraging individuals to view their home primarily as an investment, such as a mortgage tax deductions or a lending subsidy (Aalbers 2011; Crook and Kemp 2011; McCabe 2016). Theoretically, a reduction in these incentives could have downstream impacts on the financial behavior of individual homeowners and ameliorate their concomitant engagement with the politics of exclusion. As early as the 1970s, Breton (1973) proposed an insurance scheme to help homeowners offset the financial risks associated with their investment, since it cannot be otherwise diversified. As Fischel (2001) recounts,

Breton (1973) invoked economic theory to explain the existence of zoning and the difficulties it posed for developers. He identified the cause of residents' aversion to development as an incomplete insurance market. Since residents cannot insure against neighborhood change, zoning offers a kind of second-best institution. If homeowners were insured against neighborhood decline, they wouldn't worry so much about seemingly unlikely scenarios and behave like NIMBYs.

If a private market or public insurance instrument could be crafted to effectively protect against downside risk for individual homeowners against the real or perceived externalities of community development, it could reduce the incidence of exclusionary political behavior at the community level.

It is important to note that reducing, or even somehow eliminating, long-term financial risk is unlikely to eliminate NIMBY behavior altogether. Financial self-preservation is not the only or even necessarily most salient reason that homeowners engage in NIMBY behavior. Thus, even if policy actors were able to successfully de-couple housing considerations from pension and welfare concerns, it is not entirely clear that this would be sufficient to reduce NIMBY behavior in and of itself. Fischel (2004) outlines how, the suggestive evidence implies that the original implementation of land-use restriction in the United States was, at least in part, racially motivated, despite it having been specifically struck down by the courts as a legally legitimate motivation. Nonetheless, given that homeowners are often forced to couch their opposition to new development in pro-social terms (Esaiasson 2014; Hankinson 2018; Schively 2007), finding a way to diminish risk for homeowners may nonetheless remove an effective political arrow from the NIMBY quiver. Irrespective of the concrete policy channels utilized, the literature is nearly universal in its call for policy elites to take a more active role in educating everyday citizens about the affordable housing needs of their communities. These scholars call on knowledgeable actors in the housing and social policy systems to open up effective mechanisms of communication to a much broader swath of relevant stakeholders (Aalbers 2009; Fraser and Kick 2007; McCabe 2016; Sager 2011; Wolsink 2004).

By outlining the potential theoretical connection between decision making in the sphere of public pensions and decision making in the housing policy subsystem, in ways that are not necessarily intuitive, the hope is that policymaking can be improved for both. Conventional political discourse might find it a strange to suggest that the increased commodification of housing and pension systems could be a cause of community interventions 
that introduce substantial frictions into the market. However, the literature suggests that if policy and political elites accepted the premise of neoliberalism's hegemonic influence, this outcome would seem quite intuitive. The existing asymmetry in the literature, where some authors criticize the neoliberal project of commodification, while others fail to acknowledge its very existence, only serves to undermine policy debates. This has almost certainly led to some policies occupying a status of unearned political advantage while others are forced to make an uphill push against a set of hostile-and potentially uninterrogated-economic and political assumptions. Nonetheless, despite the variety of political systems, attitudes, and levels of government interventions, trends are consistent enough across much of the developed world-and comport strongly enough with our understanding of the goals of neoliberalism - to warrant robust discussion.

Funding: This research received no external funding.

Conflicts of Interest: The author declares no conflict of interest.

\section{Notes}

1 Only suggestive because while it is possible to track long-term trends in homeownership rates to an extent, data on the prevalence home-debtors over time is scant.

2 Individual data sources for Figure 2: (Anacker et al. 2019; Central Statistics Office 2016; Davis et al. 2008; Doling and Elsinga 2012; Kettenhofen 2021; Statistics Canada 2021).

3 One possible exception to this may be Chicago which saw land drop as a percentage of homes built and, generally, does not follow a development pattern similar to cities like Dallas and Pheonix. Exploring this specific case in greater detail, however, is beyond the scope of this paper.

$4 \quad$ Mirowski and Plehwe (2015) would point out that neoliberal ideology is not opposed to government interventions that prop up markets or protect stocks of wealth.

\section{References}

Aalbers, Manuel B. 2009. The Sociology and Geography of Mortgage Markets: Reflections on the Financial Crisis. International Journal of Urban and Regional Research 33: 281-90. [CrossRef]

Aalbers, Manuel B. 2011. Place, Exclusion and Mortgage Markets. Oxford: John Wiley \& Sons, vol. 37.

Aalbers, Manuel B. 2015. The Great Moderation, the Great Excess and the Global Housing Crisis. International Journal of Housing Policy 15: 43-60. [CrossRef]

American Enterprise Institute. 2021. Historical Land Price Indicators. American Enterprise Institute-AEI (blog). Available online: https: / / www.aei.org/historical-land-price-indicators / (accessed on 30 July 2021).

Amior, Michael, and Jonathan Halket. 2014. Do Households Use Home-Ownership to Insure Themselves? Evidence across US Cities. Quantitative Economics 5: 631-74. [CrossRef]

Anacker, Katrin B., Mai Thi Nguyen, and David P. Varady. 2019. The Routledge Handbook of Housing Policy and Planning. New York: Routledge.

André, Stéfanie, and Caroline Dewilde. 2016. Home Ownership and Support for Government Redistribution. Comparative European Politics 14: 319-48. [CrossRef]

Badger, Emily, and Quoctrung Bui. 2019. Cities Start to Question an American Ideal: A House with a Yard on Every Lot. The New York Times, June 18 The Upshot. Available online: https:/ /www.nytimes.com/interactive/2019/06/18/upshot/cities-across-americaquestion-single-family-zoning.html (accessed on 30 July 2021).

Beer, Andrew, and Debbie Faulkner. 2011. Housing Transitions through the Life Course: Aspirations, Needs and Policy. Bristol: Policy Press.

Blumenthal, Pamela M., John R. McGinty, and Rolf Pendall. 2016. Strategies for Increasing Housing Supply in High-Cost Cities. Washington, DC: Urban Institute.

Bond, Tyler, and Dan Doonan. 2020. The Growing Burden of Retirement. National Institute on Retirement Security. Available online: https:/ / www.nirsonline.org/reports/growingburden/ (accessed on 30 July 2021).

Bourdieu, Pierre. 1998. Neo-Liberalism, the Utopia (Becoming a Reality) of Unlimited Exploitation. In Acts of Resistance: Against the Tyrranny of the Market. France: Blackwell Publishers Ltd.

Brainard, Keith, and Alex Brown. 2018. Significant Reforms to State Retirement Systems. National Association of State Retirement Administrators. Available online: https:/ / www.nasra.org/files/Spotlight/Significant\%20Reforms.pdf (accessed on 30 July 2021).

Brennan, Maya, Pam Blumenthal, Laurie Goodman, Ellen Seidman, and Brady Meixell. 2017. Housing as an Asset Class. Available online: https:/ / www.urban.org/sites/default/files/publication/93601/housing-as-an-asset-class_0.pdf (accessed on 30 July 2021).

Breton, A. 1973. Neighborhood Selection and Zoning. In Issues in Urban Public. Edited by Harold Hochman. Saarbrucken: Institute Internationale de Finance Publique. 
Castles, Francis G. 1998. The Really Big Trade-off: Home Ownership and the Welfare State in the New World and the Old. Acta Politica 33: 5-19.

Causa, Orsetta, Nicolas Woloszko, and David Leite. 2019. Housing, Wealth Accumulation and Wealth Distribution: Evidence and Stylized Facts. OECD Economics Department Working Papers 1588. OECD Economics Department Working Papers. Available online: https://www.oecd-ilibrary.org/economics/housing-wealth-accumulation-and-wealth-distribution-evidenceand-stylized-facts_86954c10-en (accessed on 26 June 2021).

Central Statistics Office. 2016. Census of Population 2016-Profile 1 Housing in Ireland. Available online: https:/ / www.cso.ie/en/ releasesandpublications/ep/p-cp1hii/cp1hii/hs/ (accessed on 21 January 2019).

Cerny, Philip G. 2008. Embedding Neoliberalism: The Evolution of a Hegemonic Paradigm. The Journal of International Trade and Diplomacy 2: 1-46.

Chia, Ngee Choon, and Albert K. C. Tsui. 2019. Nexus between Housing and Pension Policies in Singapore: Measuring Retirement Adequacy of the Central Provident Fund. Journal of Pension Economics and Finance 18: 304-30. [CrossRef]

Christophers, Brett. 2013. A Monstrous Hybrid: The Political Economy of Housing in Early Twenty-First Century Sweden. New Political Economy 18: 885-911. [CrossRef]

Clingermayer, James C. 2004. Heresthetics and Happenstance: Intentional and Unintentional Exclusionary Impacts of the Zoning Decision-Making Process. Urban Studies 41: 377-88. [CrossRef]

Cook, Sarah. 2001. Addressing Vulnerability through Asset Building and Social Protection. In Asset-Based Welfare: International Comparisons. Edited by Sue Regan and Will Paxton. London: IPPR.

Crook, Tony, and Peter A. Kemp. 2011. Transforming Private Landlords: Housing, Markets and Public Policy. Oxford: John Wiley \& Sons, vol. 43.

Crouch, Colin. 2011. The Strange Non-Death of Neo-Liberalism. Cambridge: Polity.

Davis, Morris A., Andreas Lehnert, and Robert F. Martin. 2008. The Rent-Price Ratio for the Aggregate Stock of Owner-Occupied Housing. Review of Income and Wealth 54: 279-84. [CrossRef]

Davis, Morris A., and Michael G. Palumbo. 2008. The Price of Residential Land in Large US Cities. Journal of Urban Economics 63: 352-84. [CrossRef]

De Decker, Pascal, and Caroline Dewilde. 2010. Home-Ownership and Asset-Based Welfare: The Case of Belgium. Journal of Housing and the Built Environment 25: 243-62. [CrossRef]

Delfani, Neda, Johan De Deken, and Caroline Dewilde. 2014. Home-Ownership and Pensions: Negative Correlation, but No Trade-Off. Housing Studies 29: 657-76. [CrossRef]

Deng, F. Frederic. 2003. The Rebound of Private Zoning: Property Rights and Local Governance in Urban Land Use. Environment and Planning A 35: 133-49. [CrossRef]

Dewilde, Caroline, and Pascal De Decker. 2016. Changing Inequalities in Housing Outcomes across Western Europe. Housing, Theory and Society 33: 121-61. [CrossRef]

Di Feliciantonio, Cesare, and Manuel B. Aalbers. 2018. The Prehistories of Neoliberal Housing Policies in Italy and Spain and Their Reification in Times of Crisis. Housing Policy Debate 28: 135-51. [CrossRef]

Dietz, Robert D., and Donald R. Haurin. 2003. The Social and Private Micro-Level Consequences of Homeownership. Journal of Urban Economics 54: 401-50. [CrossRef]

Doling, John, and Marja Elsinga. 2012. Demographic Change and Housing Wealth: Home-Owners, Pensions and Asset-Based Welfare in Europe. Dordrecht: Springer Science \& Business Media.

Elledge, Jonn. 2016. Treat Houses as Assets Rather than Homes and This Is What Happens I Jonn Elledge. The Guardian, February 12. Available online: http: / www.theguardian.com/commentisfree/2016/feb/12/houses-assets-homes-housing-tenants-evicted (accessed on 30 July 2021).

Elsinga, Marja, and Joris Hoekstra. 2015. The Janus Face of Homeownership-Based Welfare. Critical Housing Analysis 2: 32-41. [CrossRef]

Elster, J. 1986. The Market and the Forum: Three Varieties of Political Theory. In Foundations of Social Choice Theory. Edited by J. Elster and A. Hyland. Cambridge: Cambridge University Press.

England, Kim, and Kevin Ward. 2016. Theorizing Neoliberalization. In Handbook of Neoliberalism. Edited by Simon Springer, Kean Birch and Julie MacLeavy. New York: Routledge.

Esaiasson, Peter. 2014. NIMBYism-A Re-Examination of the Phenomenon. Social Science Research 48: 185-95. [CrossRef]

Evans, Alan W. 2008. Economics and Land Use Planning. Oxford: John Wiley \& Sons.

Finlayson, Alan. 2009. Financialisation, Financial Literacy and Asset-Based Welfare. The British Journal of Politics \& International Relations 11: 400-421.

Fischel, William A. 2001. Why Are There NIMBYs? Land Economics 77: 144-52. [CrossRef]

Fischel, William A. 2004. An Economic History of Zoning and a Cure for Its Exclusionary Effects. Urban Studies 41: 317-40. [CrossRef]

Forrest, Ray, and Ngai Ming Yip. 2011. Housing Markets and the Global Financial Crisis: The Uneven Impact on Households. Cheltenham: Edward Elgar Publishing.

Forrest, Ray, and Yosuke Hirayama. 2015. The Financialisation of the Social Project: Embedded Liberalism, Neoliberalism and Home Ownership. Urban Studies 52: 233-44. [CrossRef] 
Fraser, James C., and Edward L. Kick. 2007. The Role of Public, Private, Non-Profit and Community Sectors in Shaping Mixed-Income Housing Outcomes in the US. Urban Studies 44: 2357-77. [CrossRef]

Gilderbloom, Ji, and Jp Markham. 1995. The Impact of Homeownership on Political Beliefs. Social Forces 73: 1589-1607. [CrossRef]

Glaeser, Edward L., and Bryce A. Ward. 2009. The Causes and Consequences of Land Use Regulation: Evidence from Greater Boston. Journal of Urban Economics 65: 265-78. [CrossRef]

Glaeser, Edward L., Joseph Gyourko, and Raven E. Saks. 2005. Why Have Housing Prices Gone Up? American Economic Review 95: 329-33. [CrossRef]

Goetz, Edward G. 2013. New Deal Ruins: Race, Economic Justice, and Public Housing Policy. New York: Cornell University Press.

Gurran, Nicole, and Glen Bramley. 2017. Urban Planning and the Housing Market: International Perspectives for Policy and Practice. London: Springer.

Hackworth, Jason. 2007. The Neoliberal City: Governance, Ideology, and Development in American Urbanism. New York: Cornell University Press.

Haffner, Marietta E.A. 2009. Bridging the Gap between Social and Market Rented Housing in Six European Countries? Amsterdam: IOS Press, vol. 33.

Hankinson, Michael. 2018. When Do Renters Behave like Homeowners? High Rent, Price Anxiety, and NIMBYism. American Political Science Review 112: 473-93. [CrossRef]

Hart, John F. 1996. Colonial Land Use Law and Its Significance for Modern Takings Doctrine. Harvard Law Review 109: 1252-1300. [CrossRef]

Hershey, Douglas A., Kène Henkens, and Hendrik P. Van Dalen. 2007. Mapping the Minds of Retirement Planners: A Cross-Cultural Perspective. Journal of Cross-Cultural Psychology 38: 361-82. [CrossRef]

Hilber, Christian A.L. 2010. New Housing Supply and the Dilution of Social Capital. Journal of Urban Economics 67: 419-37. [CrossRef]

Hodkinson, Stuart. 2011. Housing Regeneration and the Private Finance Initiative in England: Unstitching the Neoliberal Urban Straitjacket. Antipode 43: 358-83. [CrossRef]

Hollanders, David. 2016. Pension Systems Do Not Suffer from Ageing or Lack of Home-Ownership but from Financialisation. International Journal of Housing Policy 16: 404-8. [CrossRef]

Hsieh, Chang-Tai, and Enrico Moretti. 2015. Housing Constraints and Spatial Misallocation. w21154. Cambridge: National Bureau of Economic Research. [CrossRef]

Ihlanfeldt, Keith R. 2004. Exclusionary Land-Use Regulations within Suburban Communities: A Review of the Evidence and Policy Prescriptions. Urban Studies 41: 261-83. [CrossRef]

Ihlanfeldt, Keith R. 2007. The Effect of Land Use Regulation on Housing and Land Prices. Journal of Urban Economics 61: 420-35. [CrossRef]

International Monetary Fund. 2020. Household Debt, Loans and Debt Securities. IMF Global Debt Database. Available online: https:/ / www.imf.org/external/datamapper/HH_LS@GDD (accessed on 30 June 2021).

Izuhara, Misa. 2016. Reconsidering the Housing Asset-Based Welfare Approach: Reflection from East Asian Experiences. Social Policy and Society 15: 177-88. [CrossRef]

Jeszeck, Charles A., Margie K Shields, Justine Augeri, Christina Cantor, Gustavo Fernandez, Jennifer Gregory, Adam Wendel, and Seyda Wentworth. 2017. The Nation's Retirement System: A Comprehensive Re-Evaluation Is Needed to Better Promote Future Retirement Security. Government Accountability Office. Available online: https: / /www.ssrn.com/abstract=3062574 (accessed on 24 June 2021).

Jones, Colin, and Craig Watkins. 2009. Housing Markets and Planning Policy. Oxford: John Wiley \& Sons, vol. 40.

Kadi, Justin, and Richard Ronald. 2016. Undermining Housing Affordability for New York's Low-Income Households: The Role of Policy Reform and Rental Sector Restructuring. Critical Social Policy 36: 265-88. [CrossRef]

Kadi, Justin, and Sako Musterd. 2015. Housing for the Poor in a Neo-Liberalising Just City: Still Affordable, but Increasingly Inaccessible. Journal of Economic and Social Geography 106: 246-62. [CrossRef]

Kemeny, Jim. 1980. Home Ownership and Privatization. International Journal of Urban and Regional Research 4: 372-88. [CrossRef]

Kemeny, Jim. 2005. 'The Really Big Trade-Off' between Home Ownership and Welfare: Castles' Evaluation of the 1980 Thesis, and a Reformulation 25 Years On. Housing, Theory \& Society 22: 59-75. [CrossRef]

Kettenhofen, L. 2021. Japan: Home Ownership Rate 1973-2018. Statista. Available online: https://www.statista.com/statistics/100542 8/home-ownership-rate-japan/ (accessed on 30 June 2021).

Kingston, Pw, and Jc Fries. 1994. Having a Stake in the System-the Sociopolitical Ramifications of Business and Home Ownership. Social Science Quarterly 75: 679-86.

Kiyotaki, Nobuhiro, Alexander Michaelides, and Kalin Nikolov. 2011. Winners and Losers in Housing Markets. Journal of Money, Credit and Banking 43: 255-96. [CrossRef]

Knoll, Katharina, Moritz Schularick, and Thomas Steger. 2017. No Price like Home: Global House Prices, 1870-2012. American Economic Review 107: 331-53. [CrossRef]

Köppe, Stephan. 2015. Housing Wealth and Asset-Based Welfare as Risk. Critical Housing Analysis 2: 42-51. [CrossRef]

Litwin, Howard, and Adi Meir. 2013. Financial Worry among Older People: Who Worries and Why? Journal of Aging Studies 27: 113-20. [CrossRef] 
MacLeavy, Julie. 2016. Neoliberalism and Welfare. In Handbook of Neoliberalism. Edited by Simon Springer, Kean Birch and Julie MacLeavy. New York: Routledge.

Malpass, Peter. 2008. Histories of Social Housing: A Comparative Approach. In Social Housing in Europe II. Edited by Kathleen Scanlon and Christine Whitehead. London: London School of Economics.

Matejczyk, Anthony P. 2001. Why Not NIMBY? Reputation, Neighbourhood Organisations and Zoning Boards in a US Midwestern City. Urban Studies 38: 507-18. [CrossRef]

McCabe, Brian J. 2016. No Place Like Home: Wealth, Community, and the Politics of Homeownership. Oxford: Oxford University Press.

McIntyre, Zhan, and Kim McKee. 2012. Creating Sustainable Communities through Tenure-Mix: The Responsibilisation of Marginal Homeowners in Scotland. GeoJournal 77: 235-47. [CrossRef]

McKee, Kim. 2012. Young People, Homeownership and Future Welfare. Housing Studies 27: 853-62. [CrossRef]

Mirowski, Philip. 2013. Never Let a Serious Crisis Go to Waste: How Neoliberalism Survived the Financial Meltdown. New York: Verso Books.

Mirowski, Philip. 2018. Neoliberalism: The Movement that Dare Not Speak Its Name. American Affairs Journal, February 20. Available online: https: / americanaffairsjournal.org/2018/02/neoliberalism-movement-dare-not-speak-name/ (accessed on 2 July 2019).

Mirowski, Philip, and Dieter Plehwe. 2015. The Road from Mont Pelerin. Cambridge: Harvard University Press.

Monbiot, George. 2016. How Did We Get into This Mess?: Politics, Equality, Nature. New York: Verso Books.

Montgomerie, Johnna, and Mirjam Büdenbender. 2015. Round the Houses: Homeownership and Failures of Asset-Based Welfare in the United Kingdom. New Political Economy 20: 386-405. [CrossRef]

Moroni, Stefano. 2016. Interventionist Responsibilities for the Emergence of the US Housing Bubble and the Economic Crisis: 'Neoliberal Deregulation' Is Not the Issue. European Planning Studies 24: 1295-1312. [CrossRef]

Munck, Ronaldo. 2003. Neoliberalism, Necessitarianism and Alternatives in Latin America: There Is No Alternative (TINA)? Third World Quarterly 24: 495-511. [CrossRef]

OECD. 2019. Affordable Housing. In Society at a Glance 2019: OECD Social Indicators. Paris: OECD. [CrossRef]

OECD. 2021a. Household Accounts-Household Financial Assets. Available online: http://data.oecd.org/hha/household-financialassets.htm (accessed on 30 June 2021).

OECD. 2021b. Pension Spending (Indicator). Available online: http:/ / data.oecd.org/socialexp/pension-spending.htm (accessed on 30 June 2021).

OECD Affordable Housing Database. 2021a. OECD Affordable Housing Database. Housing Costs over Income. OECD Directorate of Employment, Labour and Social Affairs-Social Policy Division (blog). Available online: https://www.oecd.org/els/family/HC1 -2-Housing-costs-over-income.pdf (accessed on 30 June 2021).

OECD Affordable Housing Database. 2021b. Housing Tenures. OECD Directorate of Employment, Labour and Social Affairs-Social Policy Division (blog). 2021. Available online: https://www.oecd.org/els/family/HC1-2-Housing-costs-over-income.pdf (accessed on 30 June 2021).

Plehwe, Dieter. 2016. Neoliberal Hegemony. In Handbook of Neoliberalism. Edited by Simon Springer, Kean Birch and Julie MacLeavy. New York: Routledge.

Prince, Russell. 2016. Neoliberalism Everywhere: Mobile Neoliberal Policy. In Handbook of Neoliberalism. Edited by Simon Springer, Kean Birch and Julie MacLeavy. New York: Routledge.

Ronald, Richard. 2008. The Ideology of Home Ownership: Homeowner Societies and the Role of Housing. New York: Palgrave Macmillan.

Ronald, Richard, and Caroline Dewilde. 2017. Why Housing Wealth and Welfare? In Housing Wealth and Welfare. Gloucestershire: Edward Elgar Publishing.

Rothwell, Jonathan, and Douglas S. Massey. 2009. The Effect of Density Zoning on Racial Segregation in US Urban Areas. Urban Affairs Review 44: 779-806. [CrossRef]

Rusch, Lara. 2012. New Neighbors, Old Neighborhood: Affordable Homeownership and Engagement in an East Detroit Neighborhood. Spaces and Flows: An International Journal of Urban and ExtraUrban Studies 3: 127. [CrossRef]

Ryan-Collins, Josh, Toby Lloyd, and Laurie Macfarlane. 2017. Rethinking the Economics of Land and Housing. London: Zed Books Ltd.

Saegert, Susan, Desiree Fields, and Kimberly Libman. 2009. Deflating the Dream: Radical Risk and the Neoliberalization of Homeownership. Journal of Urban Affairs 31: 297-317. [CrossRef]

Sager, Tore. 2011. Neo-Liberal Urban Planning Policies: A Literature Survey 1990-2010. Progress in Planning 76: 147-99. [CrossRef]

Santiago, Anna M., George C. Galster, and Peter Tatian. 2001. Assessing the Property Value Impacts of the Dispersed Subsidy Housing Program in Denver. Journal of Policy Analysis and Management: The Journal of the Association for Public Policy Analysis and Management 20: 65-88. [CrossRef]

Santos, Ana C. 2016. Financialisation, Social Provisioning and Well-Being in Five EU Countries. FESSUD Working Paper Series 176. Available online: https:/ / estudogeral.sib.uc.pt/handle/10316/40972 (accessed on 13 November 2018).

Schively, Carissa. 2007. Understanding the NIMBY and LULU Phenomena: Reassessing Our Knowledge Base and Informing Future Research. Journal of Planning Literature 21: 255-66. [CrossRef]

Schwartz, Alex F. 2010. Trends, Patterns, Problems. In Housing Policy in the United States. New York: Routledge.

Schwartz, Herman, and Leonard Seabrooke. 2008. Varieties of Residential Capitalism in the International Political Economy: Old Welfare States and the New Politics of Housing. Comparative European Politics 6: 237-61. [CrossRef]

Sherraden, Michael, ed. 2005. Inclusion in the American Dream: Assets, Poverty, and Public Policy. New York: Oxford University Press.

Sowell, Thomas. 2011. The Housing Boom and Bust. New York: Basic Books, Revised edition. 
Springer, Simon, Kean Birch, and Julie MacLeavy. 2016. An Introduction to Neoliberalism. In Handbook of Neoliberalism. Edited by Simon Springer, Kean Birch and Julie MacLeavy. New York: Routledge.

Statistics Canada. 2021. Canada Home Ownership Rate | 1997-2018 I Data | 2020-2021 Forecast | Historical | Chart. Available online: https:/ / tradingeconomics.com/canada/home-ownership-rate (accessed on 30 June 2021).

Stephens, Mark, Martin Lux, and Petr Sunega. 2015. Housing: Asset-Based Welfare or the 'Engine of Inequality'? Critical Housing Analysis 2: 22-31. [CrossRef]

Touraine, Alain. 2001. Beyond Neoliberalism. Cambridge: Polity.

Walks, Alan, and Brian Clifford. 2015. The Political Economy of Mortgage Securitization and the Neoliberalization of Housing Policy in Canada. Environment and Planning 47: 1624-42. [CrossRef]

Watson, Matthew. 2009. Planning for a Future of Asset-Based Welfare? New Labour, Financialized Economic Agency and the Housing Market. Planning, Practice E Research 24: 41-56.

Wind, Barend, Philipp Lersch, and Caroline Dewilde. 2017. The Distribution of Housing Wealth in 16 European Countries: Accounting for Institutional Differences. Journal of Housing and the Built Environment 32: 625-47. [CrossRef] [PubMed]

Wolsink, Maarten. 2004. Policy Beliefs in Spatial Decisions: Contrasting Core Beliefs Concerning Space-Making for Waste Infrastructure. Urban Studies 41: 2669-90. [CrossRef]

World Bank. 2021. Population Ages 65 and above, Total I Data. World Bank Data. Available online: https://data.worldbank.org/ indicator/SP.POP.65UP.TO (accessed on 30 June 2021). 